
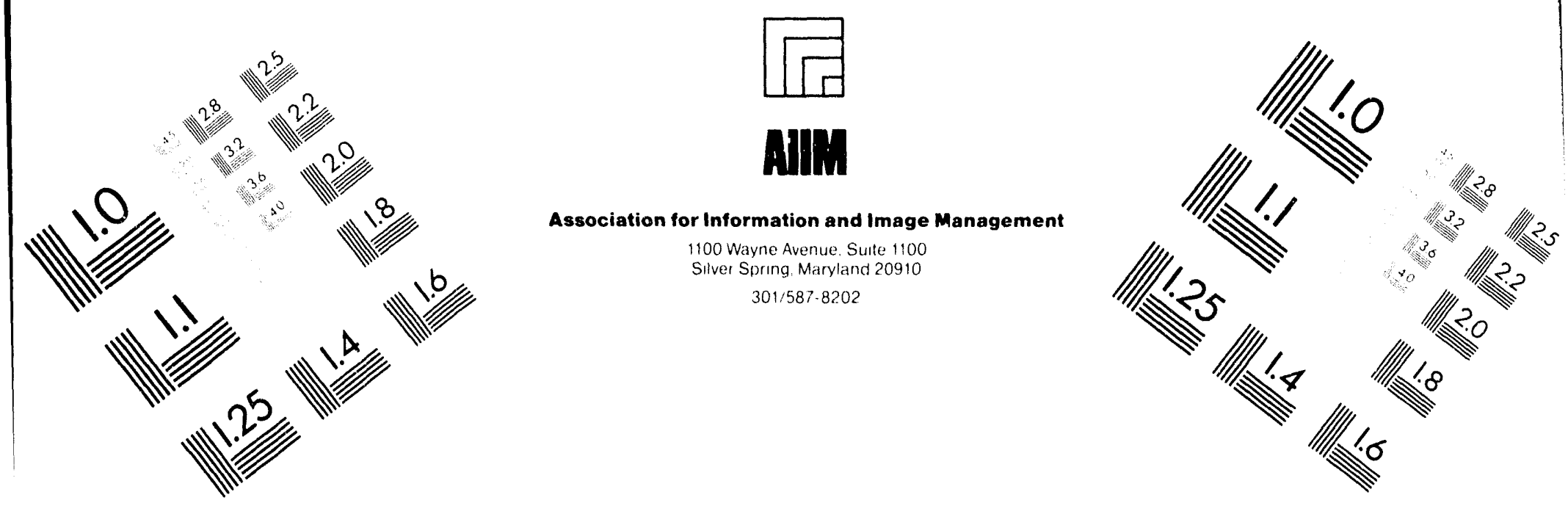

\title{
Centimeter
}

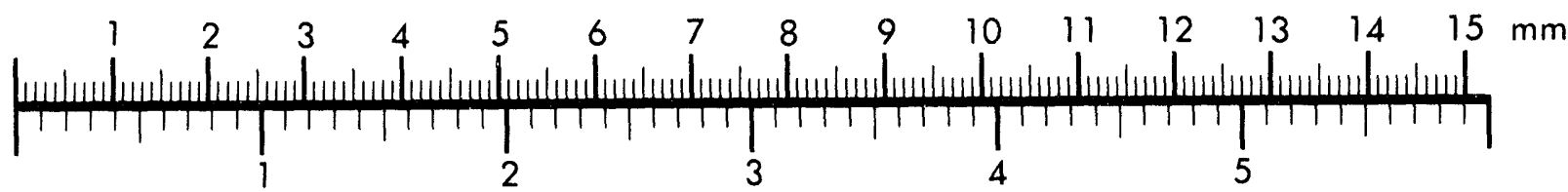

Inches
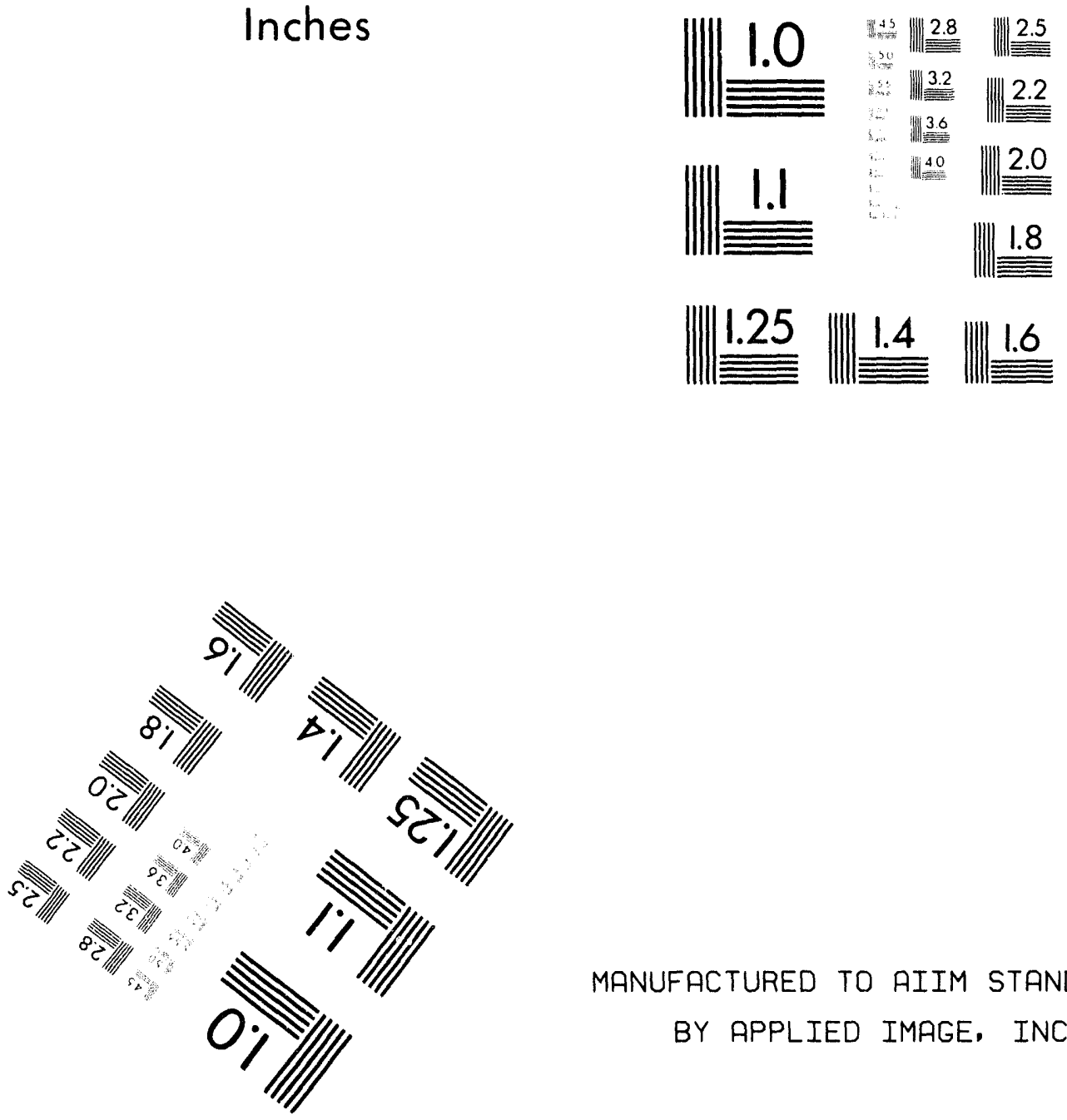

MANUFACTURED TO AIIM STANDARDS

BY APPLIED IMAGE, INC.

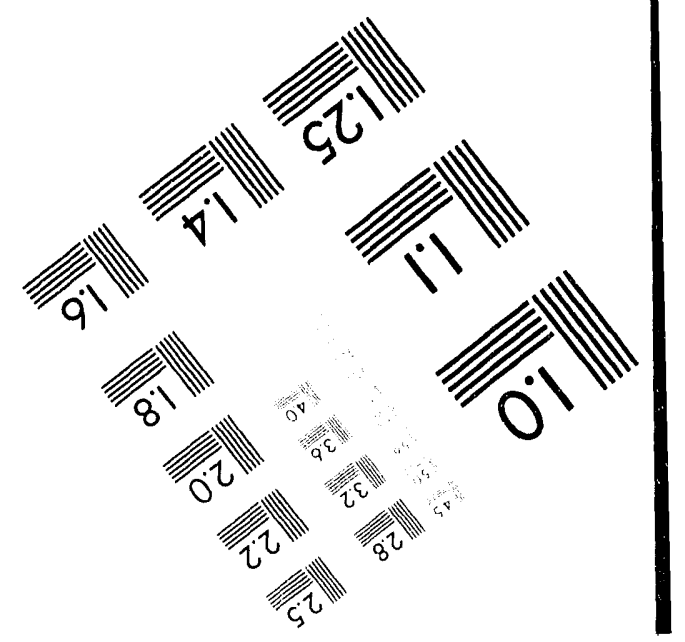



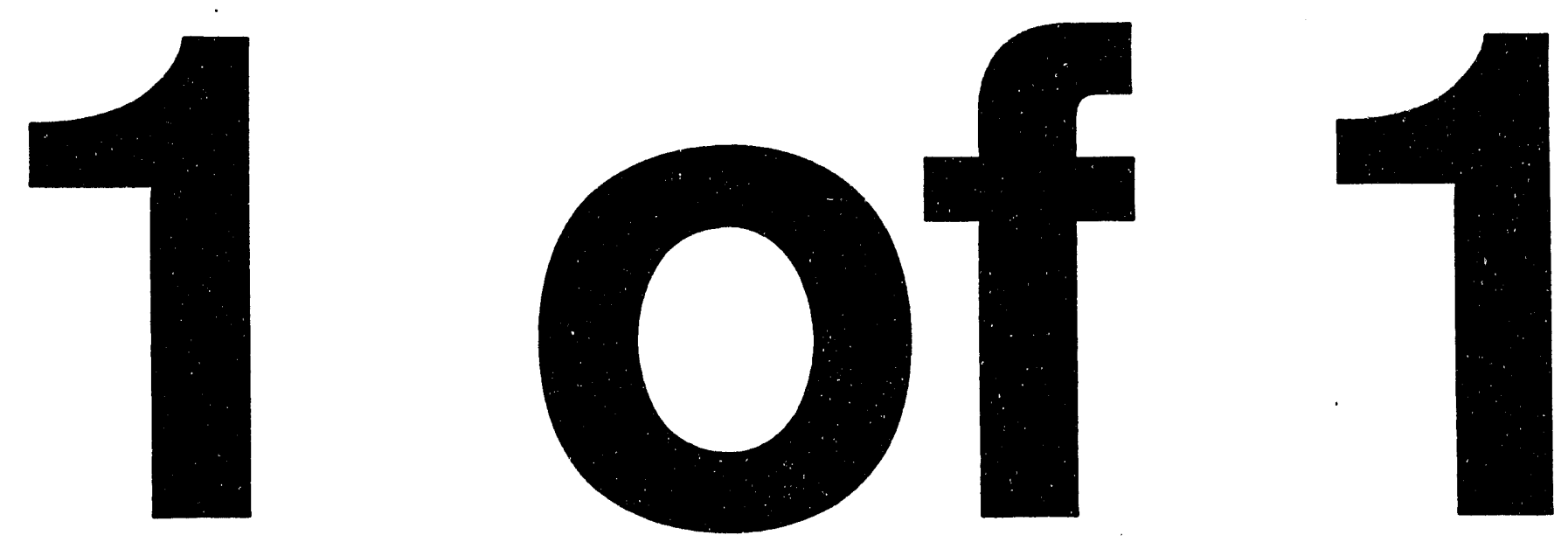
RFP -4833

\section{ANALYSIS OF OFFSITE EMERGENCY PLANNING ZONES (EPZs) FOR THE ROCKY FLATS PLANT}

\section{PHASE III}

\section{SITEWIDE SPECTRUM-OF-ACCIDENTS AND BOUNDING EPZ ANALYSIS}

\section{PROJECT PLAN}

A. J. Petrocchi, Program Administrator

G. A. Zimmerman, Principal Investigator

March 14, 1994

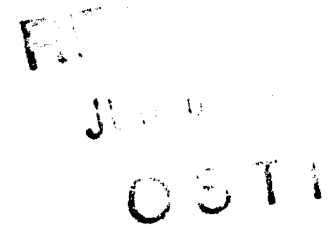

\section{ELELG ROCKY FLATS}

P.O. Box 464

Golden, Colorado 80402-0464 


\section{TABLE of CONTENTS}

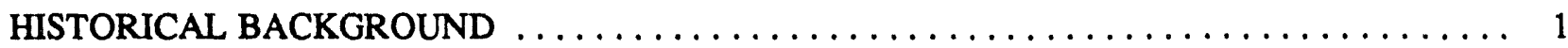

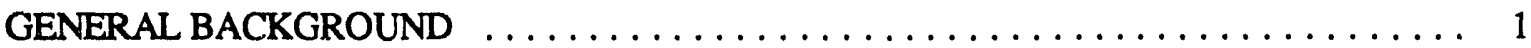

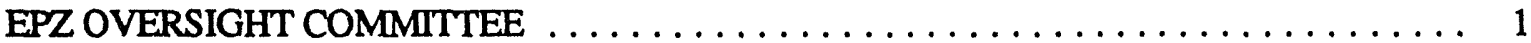

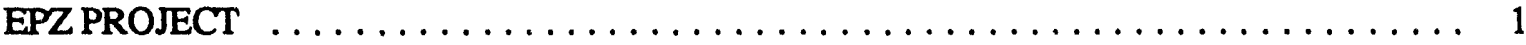

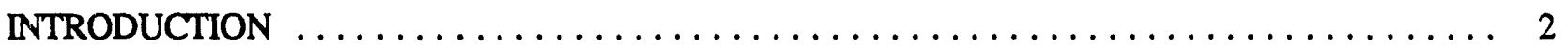

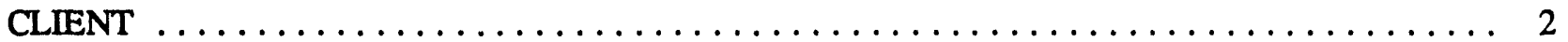

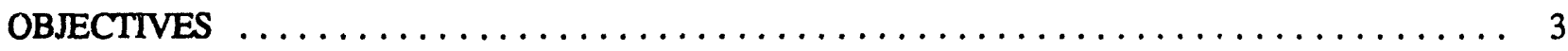

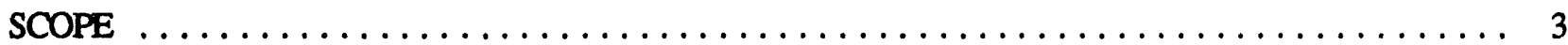

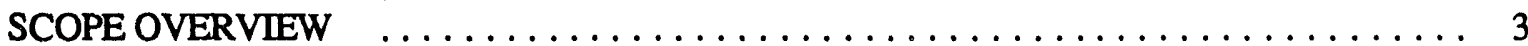

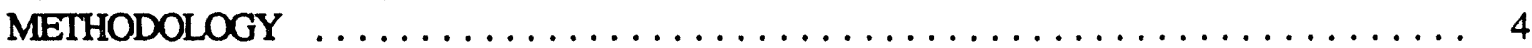

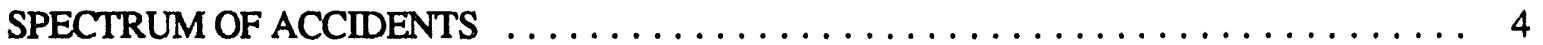

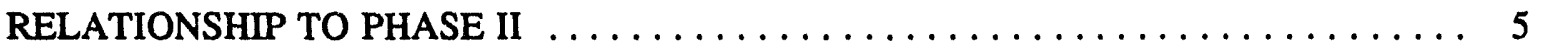

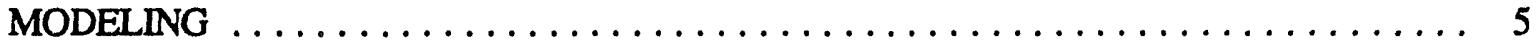

RATIONALE FOR CHANGE TO ORIGINAL PHASE III DIRECTION $\ldots \ldots \ldots \ldots \ldots \ldots$

UPDATING MECHANISM $\ldots \ldots \ldots \ldots \ldots \ldots \ldots \ldots \ldots \ldots \ldots \ldots \ldots$

RELATIONSHIP TO OTHER HAZARDS ASSESSMENT EFFORTS $\ldots \ldots \ldots \ldots \ldots \ldots \ldots$

SUMMARY OF MAJOR PHASE III TASKS $\ldots \ldots \ldots \ldots \ldots \ldots \ldots \ldots \ldots \ldots \ldots \ldots$

DESCRIPTION OF PHASE III TASKS $\ldots \ldots \ldots \ldots \ldots \ldots \ldots \ldots \ldots \ldots \ldots \ldots \ldots \ldots$

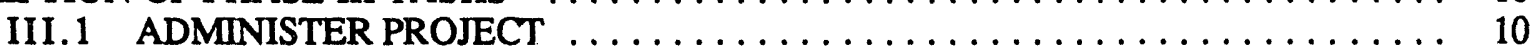

III.1.1 Obtain Necessary Staffing . . . . . . . . . . . . . . . . . . . 11

III.1.2 Develop Project Plan and Schedule $\ldots \ldots \ldots \ldots \ldots \ldots \ldots \ldots 11$

III. 1.3 Monitor/Coordinate Project Progress . . . . . . . . . . . . . . . 11

III.1.4 Act as Liaison Among Oversight Groups $\ldots \ldots \ldots \ldots \ldots \ldots \ldots 11$

III.1.5 Provide Technical/Administrative/Clerical Support $\ldots \ldots \ldots 12$

III.2 IDENTIFY HAZARDS ASSESSMENT METHODOLOGY $\ldots \ldots \ldots \ldots \ldots \ldots \ldots 12$

III. 3 DEFINE SPECTRUM OF ACCIDENTS $\ldots \ldots \ldots \ldots \ldots \ldots \ldots \ldots \ldots \ldots \ldots \ldots \ldots \ldots$

III.4 UPDATE RADIOLOGICAL RELEASE FRACTIONS $\ldots \ldots \ldots \ldots \ldots \ldots \ldots \ldots \ldots$

III.5 DEVELOP SOURCES AND SCENARIOS FOR HAZMAT AND

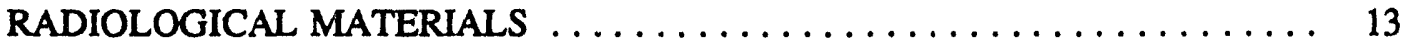

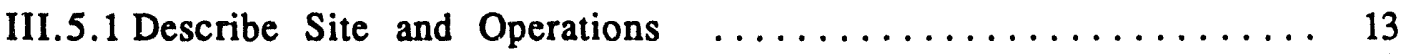

III.5.2 Screen Hazardous Substances . . . . . . . . . . . . . . . . . 13

III.5.3 Develop Basis for Interim Operation (BIO) Documentation and Facility Hazards Analyses .................. 14

III.5.4 Develop EPZ Sitewide Hazards Assessment .............. 15

III.5.5 Develop Site Safety Analysis Report ................ 15

III.5.6 Characterize Hazardous Substances $\ldots \ldots \ldots \ldots \ldots \ldots \ldots \ldots$

III.5.7 Develop Scenarios . . . . . . . . . . . . . . . . . . . 16

\section{DISCLAIMER}

This report was prepared as an account of work sponsored by an agency of the United States Government. Neither the United States Government nor any agency thereof, nor any of their employees, makes any warranty, express or implied, or assumes any legal liability or responsibility for the accuracy, completeness, or usefulness of any information, apparatus, product, or process disclosed, or represents that its use would not infringe privately owned rights. Reference herein to any specific commercial product, process, or service by trade name, trademark, manufacturer, or otherwise does not necessarily constitute or imply its endorsement, recommendation, or favoring by the United States Government or any agency thereof. The views and opinions of authors expressed herein do not necessarily state or reflect those of the United States Government or any agency thereof.
EPZ Phase III Project Plan March 14, 1994 
III. 6 CONDUCT CONSEQUENCE MODELING FOR HAZMAT AND

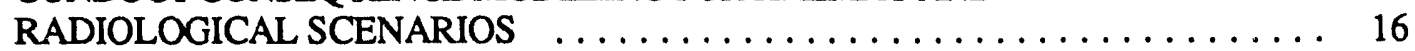

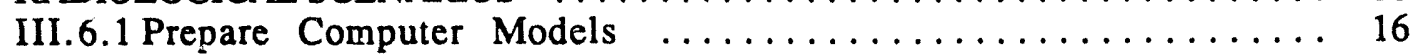

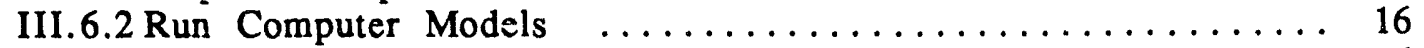

III.6.3 Evaluate Results ........................ 16

III.7 ASSURE QUALITY OF PROJECT PROCESSES AND RESULTS $\ldots \ldots \ldots \ldots \ldots 17$

III.7.1 Develop Quality Assurance Plan $\ldots \ldots \ldots \ldots \ldots \ldots \ldots \ldots \ldots \ldots$

III.7.2 Maintain QAP and Develop Records ... . . . . . . . . . . 18

III.7.3 Develop Quality Assurance Report ................ 18

III. 8 DOCUMENT PROJECT PROCESSES, PROGRESS, AND RESULTS $\ldots \ldots \ldots \ldots \quad 18$

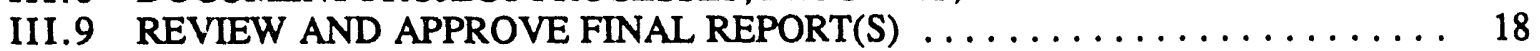

III.9. i Emergency Preparedness Review and Approval ......... 19

III.9.2 EG\&G Management Review and Approval ............. 19

III.9.3 DOE/RFO Review and Approval . . . . . . . . . . . . . . . . 19

III.9.4 EPZ Oversight Committee Review and Concurrence ........ 19

III.9.5 Publish and Distribute Final Report ............... 19

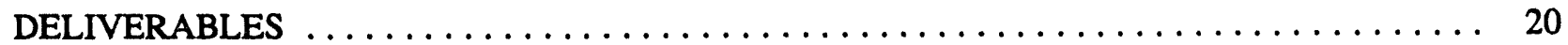

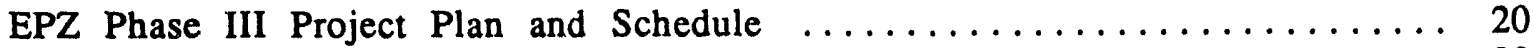

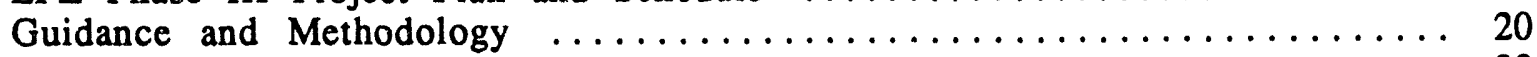

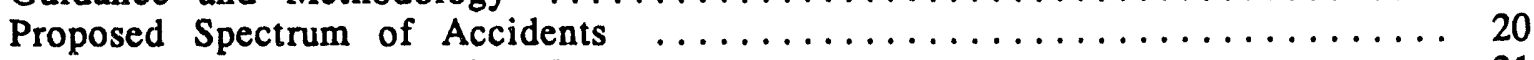

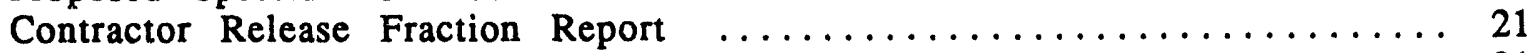

Updated Rocky Flats Plutonium Release Fractions ............... 21

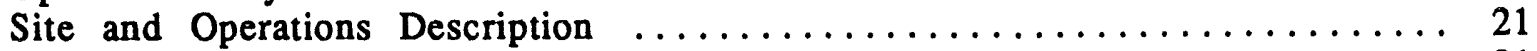

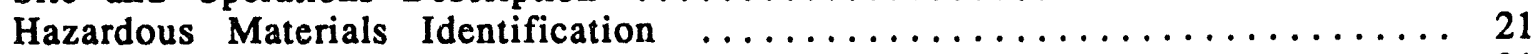

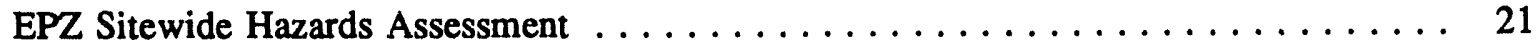

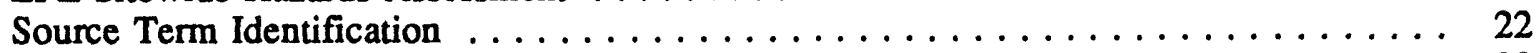

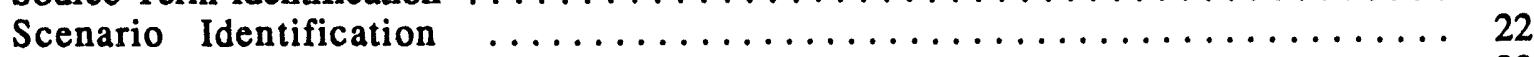

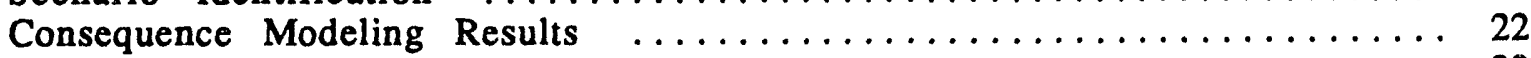

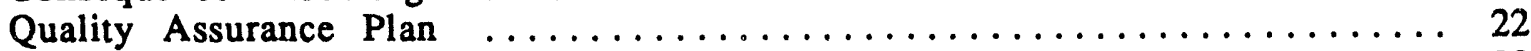

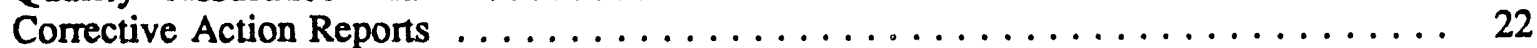

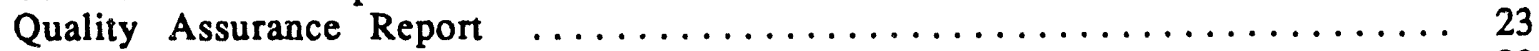

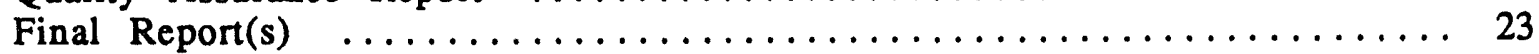

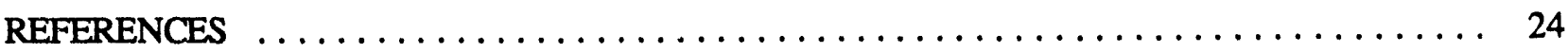

APPENDIX A: MILESTONES BASED ON EPZ AND SITE SAR INTEGRATED PROCESS $\ldots \ldots 26$

APPENDIX B: EMERGENCY PLANNING ZONE OVERSIGHT COMMITTEE CONCURRENCE SIGNATURES $\ldots \ldots \ldots \ldots \ldots \ldots \ldots \ldots \ldots \ldots \ldots$

EPZ Phase III Project Plan

March 14, 1994 


\section{HISTORICAL BACKGROUND}

\section{GENERAL,BACKGROUND}

The State of Colorado, with support from the U.S. Department of Energy Rocky Flats Office (DOE/RFO) and Rocky Flats contractors, has developed emergency plans and Emergency Planning Zones (EPZs) for the Rocky Flats Plant and has reevaluated them periodically beginning in 1980 . In the fall of 1988, Governor Romer requested a review of the EPZs for the Rocky Flats Plant. As a result, the Colorado Department of Health (CDH), DOE/RFO, and Rockwell International (the Rocky Flats contractor at the time), began a joint review in December 1988.

In the report entitled, "Analysis of Offsite Emergency Planning Zones for the Rocky Flats Plant - Overview,"1 EG\&G Rocky Flats, Inc. defined the continuation, refinement, and expansion of the technical EPZ analysis, which was begun in December 1988. The overall project includes four phases that allow DOE/RFO and EG\&G Rocky Flats, Inc. to conduct phased hazards assessments within a committed schedule, respond effectively to new expectations, and incorporate new technology and approaches as they become available.

\section{EPZ OVERSIGHT COMMITTEE}

An EPZ Oversight Committee was formally established to oversee the progress and direction of the EPZ project. The Committee is currently composed of an interagency team of federal, state, and local agencies. Current members are DOE/RFO, CDH, U. S. Environmental Protection Agency (EPA) Region VIII Office, Jefferson County, and Boulder County. The EPZ Phase III Charter ${ }^{2}$ establishes roles and responsibilities for each agency.

\section{EPZPROJECT}

There are four phases in the EPZ project. Phase I was the fourth (1988-1991) review of the Maximum Credible Accident (MCA) as the bounding radiological release 
scenario for the Rocky Flats Plant. ${ }^{3}$ Phase II used the MCA, existing dispersion methodologies, and upgraded dosimetry methodologies to identify interirn dose-vsdistance relationships as information for the State's emergency plan update for radiological releases from the Rocky Flats Plant. ${ }^{4}$ This phase also identified a screening-level EPZ for nonradiological chemically hazardous material releases. 5 Phases I and II are complete. We are now beginning Phase III, "Sitewide Spectrumof-Accidents and Bounding EPZ Analysis." This Phase is intended to upgrade our interim EPZ analyses, adding an advanced determination of plutonium release fractions and a comprehensive sitewide review of both radiological and nonradiological hazardous materials scenarios leading to a bounding EPZ determination. Phase IV will be a comprehensive, building-by-building hazards analysis that is intended to refine the Phase III bounding EPZ.

Since the time this project was started, the world and the Rocky Flats Plant have seen dramatic changes. With the collapse of the former Soviet Union has come a drastically reduced emphasis in this country on nuclear weapons production. As a result, the Rocky Flats Plant has begun a transition from a nuclear weapons production mission to a decontamination and decommissioning mission. In spite of the end to the production mission, there are and will continue to be significant quantities of radiological and nonradiological hazardous materials at the Rocky Flats Plant for the foreseeable duration of the Plant's remaining lifetime. As a result, the EPZ Oversight Committee remains committed to the EPZ project.

\section{INTRODUCTION}

This project plan was developed with extensive review and comment from the EPZ Oversight Committee. It outlines the design and identifies the deliverables of the EPZ Phase III project.

\section{CLIENT}

As stated in the EPZ Phase III Charter ${ }^{2}$, the State of Colorado is the client for this project. 


\section{OBJECTIVES}

During Phase III of the EPZ project, a sitewide analysis will be performed applying a spectrum-of-accidents approach to both radiological and nonradiological hazardous materials release scenarios. This analysis will include the MCA but will be wider in scope and will produce options for the State of Colorado for establishing a bounding EPZ that is intended to more comprehensively update the interim, preliminary EPZ developed in Phase II.

EG\&G will propose use of a hazards assessment methodology that is consistent with the DOE Emergency Management Guide for Hazards Assessment 6 and other methods required by DOE orders. This will include hazards, accident, safety, and risk analyses. Using this methodology, EG\&G will develop technical analyses for a spectrum of accidents. The analyses will show the potential effects from the spectrum of accidents on the offsite population together with identification of offsite vulnerable zones and areas of concern. These analyses will incorporate state-of-the-art technology for accident analysis, atmospheric plume dispersion modeling, consequence analysis, and the application of these evaluations to the general public population at risk. The analyses will treat both radiological and nonradiological hazardous materials and mixtures of both released accidentally to the atmosphere.

DOE/RFO will submit these results to the State of Colorado for the State's use in determining offsite emergency planning zones for the Rocky Flats Plant. In addition, the results will be used for internal Rocky Flats Plant emergency planning.

\section{SCOPE}

\section{SCOPE OVERVIEW}

EPZ Phase III will address a sitewide hazards assessment of the Rocky Flats Plarit using a spectrum-of-accidents approach. The study will include both radioactive and nonradioactive hazardous materials and establish a sitewide EPZ bounding condition. 
The material-at-risk information will be derived from individual building chemical and radiological inventories. This will preserve the building location for each scenario. The scenario building location will assist the State with their response activities in the early stages of an emergency when only the building location might be known.

\section{METHODOLOGY}

DOE's Emergency Management Guide for Hazards Assessment 6 is guidance that DOE Headquarters provides for DOE facility use. Deviations from the guidance are allowed with DOE Headquarters approval. The EPZ Oversight Committee will review and have oversight concurrence on the Rocky Flats recommended hazards assessment approach. This approach will be based on the DOE Headquarters guidance mentioned above as well as other involved DOE orders and any additional guidance on which the EPZ Oversight Committee reaches concurrence.

\section{SPECTRUM OE ACCIDENTS}

The spectrum of accidents for Phase III will be grouped into external and internal events. External events will include natural phenomena such as earthquakes, tornadoes, wind storms, and floods. This class also includes human-caused events, whether unintentional or intentional, such as missile attacks, airplane crashes, and bomb threats. Internal events will include operational occurrences such as fires, explosions, nuclear criticality, spills, and equipment failures with material in storage or in transit.

In this Plan, "scenario" is used as the story that provides the surrounding details and consequences of an initiating accident resulting in an event that releases or has the potential to release hazardous materials. An "accident" is the result of an initiating event for the scenario. 


\section{RELATIONSHIP TO PHASE II}

In Phase II, a preliminary screening analysis was performed for nonradiological hazardous material (HAZMAT) releases. Only one scenario was used, that of a catastrophic rupture and short-duration release of the single largest container in any one location. In Phase III, a comprehensive review of potential scenarios will be performed against the defined spectrum of accidents. Part or all of the hazardous materials inventory at any one location will be involved depending on the scenario.

Radiological material releases will receive the same type of in-depth analysis as for HAZMAT releases. In addition, the release fraction upgrade for radiological material releases, originally scheduled for Phase II, has oeen moved to Phase III in response to difficulties in obtaining critical contracted services.

\section{MODELNNG}

Atmospheric dispersion and consequence modeling will be performed using a suite of models. The suite of models will include the Terrain-Responsive Atmospheric Code (TRAC) model when it is accepted for use by the State of Colorado. TRAC is a state-ofthe-art complex-terrain atmospheric dispersion model developed at the Rocky Fiats Plant. It is currently in the final stages of a State-acceptance process. In the interim, other government "accepted" models will be used although TRAC results will continue to be used as a comparison to these other models. Other government "accepted" models will include the Nuclear Regulatory Commission REG GUIDE 1.145 Atmospheric Dispersion Model for Potential Accident Consequence Assessments at Nuclear Power Plants for radiological releases and the Areal Locations of Hazardous Atmospheres (ALOHA) model for nonradiological releases. After the TRAC Stateacceptance process is complete, REG GUIDE 1.145 will be used as a backup and comparison to TRAC. ALOHA has a heavy gas modeling capability and will continue to be used for modeling this type of release even after the TRAC acceptance process is complete because TRAC currently does not have this capability. Development and implementation of a heavy gas modeling capability for TRAC is planned for FY94 and FY95. When it is ready, it will be used in preference to ALOHA. The Automated Resource for Chemical Hazard Incident Evaluation (ARCHIE) model will be used for 
fire/explosion scenarios. With the exception of TRAC, all of these models are straight-line Gaussian models that assume flat terrain and uniform, unchanging meteorological conditions.

Other models will be used on an as-needed special-requirement basis. This may include such models as the Melcor Accident Consequence Code System (MACCS), the Industrial Source Complex (ISC), or other specialized models subject to EPZ Oversight Committee concurrence.

\section{RATIONALE FOR CHANGE TO ORIGINAL PHASE III DIRECTION}

EPZ Phase III will be based on an approach integrating the EPZ analysis with the Sitewide Safety Analysis Report (SAR) effort rather than an independent EPZ analysis. This represents a change to the original direction for this phase, which was a building-by-building approach for eleven high-priority buildings. To document the rationale for this change in direction, advantages and disadvantages of these different approaches are discussed below.

Preliminary estimates placed the integrated approach at just over half a year longer than the non-integrated approach. However, recent discussions with the sitewide SAR group are showing no significant time savings for either approach. Current estimates are that the integrated approach can be completed in roughly two years beginning with FY94. Integration considerations to define tasks and milestones will be presented to the Oversight Committee as they become available. Current estimated milestones are presented in Appendix A.

Advantages of a sitewide EPZ/SAR integrated process are:

- Consistency of methodology and results,

- More up-to-date and accurate material-at-risk and building configuration information,

- Economy of resources since one FTE (full time equivalent) would be working on the sitewide EPZ hazards assessment as an integrated effort with the sitewide SAR process. 
A disadvantage is:

- An integrated effort may take longer to complete than a non-integrated effort although recent discussions indicate no significant time difference.

Advantages of an independent, non-integrated EPZ process are:

- Mutual cross-check of results,

- This approach may be finished earlier than the integrated approach although, as mentioned above, recent discussions indicate no significant time difference.

Disadvantages are:

- Risk of inconsistent methodology and results,

- Possible duplication of effort between the sitewide EPZ and SAR processes,

- Lack of rigor and possible inability to reflect up-to-date material at risk and building configuration.

Advantages of either sitewide approach over a building-by-building approach are:

- Availability of results for the State at least two and possibly three years earlier than by a building-by-building process for eleven high-priority buildings,

- Uniformly current results rather than a six-year spread in results ranging from obsolete to up-to-date in the building-by-building approach.

- A bounding analysis will assure appropriate planning needs are met while the Plant is going through its mission transition period. 


\section{UPDATING MECHANISM}

To assure that new or changed activities do not adversely affect sitewide bounding analyses once Phase III is finished, an updating function will be accomplished through the Unreviewed Safety Question (USQ) Determination process.

A USQ Determination is a

safety evaluation performed by a Certified Evaluator to determine if a proposed change, test, or experiment involves an unreviewed safety question, or would violate a TSR [Technical Safety Requirement], require changes to the TSR, exceed criticality safety acceptance criteria, involve a new or increased risk involving nonradiological hazardous materials, or require a change to the FSAR [Final Safety Analysis Report]. ${ }^{7}$

Technical Safety Requirements

define the bounding conditions for safe operation, and bases thereof, and the management or administrative controls required to ensure the safe operation of a nuclear facility. 8

The USQ Determination process provides quantitative and qualitative risk-based analyses in conformance with DOE orders relating to unreviewed safety questions and safety of nuclear facilities. ${ }^{9}$

The concept of the Unreviewed Safety Question was established to allow contractors to make physical and procedural changes and to conduct tests and experiments without prior DOE approval, as long as these changes do not explicitly or implicitly affect the authorization basis of the facility or result in a Technical Safety Requirement change.8

A USQ Determination is required for:

- Temporary or permanent changes in the facility as described in the existing authorization basis documents,

- Temporary of permanent changes in the procedures as described in existing authorization basis documents,

- Tests or experiments not described in existing authorization basis documents, or

- Discovery of information that indicates a potential inadequacy of previous Safety Analyses or a possible reduction in the margin of safety as defined in [Technical] Safety Requirements. ${ }^{9}$

A USQ is deemed to be involved in a proposed change, test, experiment, or analytic 
inadequacy if any of these could:

- Increase the probability of occurrence or the consequences of an accident or malfunction of equipment important to safety previously evaluated by safety analyses,

- Create the possibility for an accident or malfunction of a different type than any evaluated previously by safety analyses, or

- Reduce any margin of safety, as defined in the basis for any Technical Safety Requirement (TSR). 8

When a USQ is identified, EG\&G Emergency Preparedness will review it for any impacts on the EPZ, the State will be notified, and a briefing will be given to the EPZ Oversight Committee.

In summary, the USQ Determination process assures that changes to the plant safety envelop are adequately reviewed for safety impacts and appropriately modified, if necessary, or approved prior to implementation.

\section{RELATIONSHIP TO OTHER HAZARDS ASSESSMENT EFFORTS}

Several Rocky Flats Plant groups are currently developing hazards assessments from various perspectives to meet a wide variety of regulatory requirements. These groups have a common need to perform hazards assessments but lack coordination to utilize resources efficiently. To better manage these efforts, an Integrated Safety Assessment (ISA) group has developed a plan to coordinate these efforts. This includes the EPZ and Sitewide SAR efforts. One of the goals of this group is to make the core hazards assessment a common product that all of these groups can then apply to a variety of end uses.

These efforts are in large part building-by-building hazards assessments. If the ISA effort proceeds as currently intended, these hazards assessments can be used in portions of Phase III as well as later in Phase IV with appropriate updating. 
In addition, the Plutonium Release Fraction Final Report developed within the EPZ Phase III project will be shared with other groups at the Rocky Flats Plant doing work with release fractions.

\section{SUMMARY OF MAJOR PHASE III TASKS}

The following is a summary of the major Phase III tasks:
III.1 Administer Project
III.2 Identify Hazards Assessment Methodology
III.3 Define Spectrum of Accidents
III.4 Update Radiological Release Fractions
III.5 Develop Sources and Scenarios for HAZMAT and Radiological Materials
III.6 Conduct Consequence Modeling for HAZMAT and Radiological Scenarios
III.7 Assure Quality of Project Processes and Results
III. 8 Document Project Processes, Progress, and Results
III.9 Review and Approve Final Report

\section{DESCRIPTION OF PHASE III TASKS}

Deliverables and milestones for each of the tasks and subtasks described in this section may be found in the "Deliverables" section immediately following this section and in Appendix A, "Milestones Ysed on EPZ and Site SAR Integrated Process" respectively.

The following is a description of all Phase III tasks and subtasks:

\section{1 ADMINISTER PROJECT}

Program Administrator: A.J. Petrocchi, Emergency Preparedness Offsite Programs

The Program Administrator will coordinate and administer the EPZ Phase III Project 
to ensure that the project objectives are fully met within the committed schedule and resources.

III.1.1 Obtain Necessary Staffing

The Program Administrator will identify and request the appropriate staffing needed to accomplish the required scope of work. Staff will be requested as necessary to ensure a total level-of-effort that will meet all schedules at the needed level-of-quality.

III.1.2 Develop Project Plan and Schedule

The Program Administrator will coordinate with the EPZ Oversight Committee to develop a Project Plan and Schedule. The plan will include identification of tasks, task interrelationships, task scheduling, resource identification, and resource allocation.

\section{III.1.3 Monitor/Coordinate Project Progress}

The Program Administrator will coordinate technical efforts for the project. He will monitor the progress of all technical tasks and will track the project progress against the schedule identified in the Project Plan. He will adjust allocation of resources and staff efforts as necessary to ensure that the project objectives are met on schedule.

\section{III.1.4 Act as Liaison Among Oversight Groups}

The Program Administrator will act as a liaison among EG\&G management, DOE/RFO management, the Colorado Department of Health, the U.S.

Environmental Protection Agency Region VIII Office, Jefferson and Boulder Counties, and other external groups as appropriate. The Program Administrator will conduct this liaison effort to ensure that Phase III satisfies the needs of the State of Colorado and reflects the concurrence of the EPZ Oversight Committee. The Program Administrator will conduct oversight 
review meetings at monthly or as-needed intervals to keep management and external groups informed of the progress of the project.

\section{III.1.5 Provide Technical/Administrative/Clerical Support}

\section{Emergency Preparedness Offsite Programs and Safety Analysis Engineering} personnel will provide technical, administrative, and clerical support to the technical teams performing tasks in this project. Support will include research, technical expertise, data compilation, word processing, and filing.

\section{2 IDENTIFY HAZARDS ASSESSMENT METHODOLOGY}

\section{Task Leader: G.A. Zimmerman, Safety Analysis Engineering}

The task leader is responsible for recommending to the EPZ Oversight Committee the methodology to be used for hazards assessment in Phase III. The methodology to be used will be primarily the DOE Emergency Management Guide for Hazards Assessment 6 and other DOE Orders, as appropriate. If the EPZ Oversight Committee requests significant changes to the DOE guidance, approval for these changes will be sought through the DOE Headquarters "cognizant Program Secretarial Officer (PSO), with concurrence by the Director of Emergency Operations (DEO)" 6 as specified in the DOE guidance.

\section{III.3 DEFINE SPECTRUM OF ACCIDENTS}

Task Leader: G.A. Zimmerman, Safety Analysis Engineering

The task leader will recommend to the EPZ Oversight Committee the spectrum of accidents to be used in Phase III. The spectrum of accidents will include those involving radiological materials, nonradiological materials, and a combination of both radiological and nonradiological materials. The spectrum of accidents will include external events and internal events. External events will include such events as earthquakes, tornadoes, wind storms, floods (primarily detention pond dam breaks), airplane crashes, vehicle transportation accidents, and terrorist acts such as 
missile attacks and bomb threats. Internal events will include such events as fires, explosions, nuclear criticality, spills, and equipment failures with material in storage or in transit.

\section{III.4 UPDATE RADIOLOGICAL RELEASE FRACTIONS}

Task Leader: H. Jordan, Nuclear Safety Engineering

The Radiological Release Fractions Update contract will provide a current basis for selection of release fractions for radiological materials involved in a fire scenario. Release fractions are an integral part of hazards assessments for radiological releases. The Task Leader will coordinate the contract and provide the contract results to the Program Administrator for use in the Phase III analyses.

\section{III.5 DEVELOP SOURCES AND SCENARIOS FOR HAZMAT AND RADIOLOGICAL MATERIALS}

Task Leader: G.A. Zimmerman, Safety Analysis Engineering

\section{III.5.1 Describe Site and Operations}

The description of the site and operations will allow the task leader to identify where and how hazardous substances are used and which operations are likely to be hazardous.

\section{III.5.2 Screen Hazardous Substances}

This subtask will screen the chemical (nonradiological) and radiological sources present at the facility for selection by comparison with the following selection criteria:

- Superfund Amendments and Reauthorization Act (SARA) Title III, also known as the Emergency Planning and Community Right-To-Know Act (EPCRA) of 1986 list of Extremely Hazardous Substances (EHSs) in 40 CFR 
355 ,

- SARA Title III list of Toxic Chemicals in 40 CFR 372,

- Clean Air Act Amendments (CAAA) list of Regulated Substances for Accidental Release Prevention in 40 CFR 68,

- List of Highly Hazardous chemicals, Toxics and Reactives in 29 CFR 1910.119,

- List of Hazardous Substances and Reportable Quantities from the Comprehensive Environmental Response, Compensation, and Liability Act (CERCLA) of 1980 in 40 CFR 302.4

- Chemical lists from the Colorado Air Quality Control Commission's Regulations Number 3 and Number 8 ,

- Nuclear Regulatory Commission Quantities of Radioactive Materials Requiring Consideration of the Need for an Emergency Plan for Responding to a Release listed in 10 CFR 30.72,

- Radionuclides from the CERCLA List of Hazardous Substances and Reportable Quantities in 40 CFR 302.4, Appendix B, and

- Table A.1, Thresholds for Radionuclides in U. S. Department of Energy Standard 1027-92, "Hazard Categorization and Accident Analysis Techniques for Compliance with DOE Order 5480.23, Nuclear Safety Analysis Reports."

This screening will include consideration of those materials that may not have an offsite effect but may aggravate an incident or impede a response. In addition, solid materials and combustion/degradation by-products that would be produced in a fire or similar scenario will be included.

This activity will produce a list of those materials that could result in an offsite hazard and that need to be further evaluated. As an aid to emergency response activities, particularly in the early stages, the list will be developed in such a way that the building location of each hazardous substance is identified and preserved throughout the analysis and into the final report.

III.5.3 Develop Basis for Interim Operation (BIO) Documentation and Facility Hazards Analyses 
As part of the implementation plan for compliance with DOE Order 5480.23, "Nuclear Safety Analysis Reports,"10 Nuclear Safety Engineering is required to prepare and submit "a preliminary assessment of facility hazards, ... , bases for interim operation or restrictions on interim operations" which are referred to as the Basis for Interim Operation (BIO). The BIO establishes an interim safety basis for a specific facility, activity, or site. Although BIOs have been submitted to DOE for the fourteen facilities at the Rocky Flats Plant in hazard categories 1, 2, and 3, they must be updated before they can be incorporated into the Site SAR. This work is being performed as a Site SAR effort integrated with the EPZ Phase III project and will supply information needed for the EPZ project.

\section{III.5.4 Develop EPZ Sitewide Hazards Assessment}

Products developed in the Site SAR project (see Task III.5.5) will be used to develop the EPZ Sitewide Hazards Assessment. This effort will include an evaluation of sitewide accidents as well as prevention, detection, and mitigation systems and controls associated with the identified hazards. This will address approximately 40 facilities as well as non-facility activities, such as transportation and environmental remediation identified and evaluated in the Site SAR effort.

\subsubsection{Develop Site Safety Analysis Report}

This is not an EPZ Phase III task and is included here for information purposes since products from the Site SAR will be used in the EPZ Sitewide Hazards Assessment. The Site SAR hazards assessment and BIO documents will be compiled and integrated to develop the Site SAR. The Site SAR will analyze normal, abnormal, and accident conditions within facilities, and will also involve the evaluation of non-facility specific hazards such as transportation and environmental remediation.

\section{III.5.6 Characterize Hazardous Substances}


The hazardous materials screened from the previous subtasks will be further evaluated. Operations in which the materials are used, locations where the materials are stored, and toxic properties of the hazardous materials will be examined in more detail for each substance. As a result of this subtask, source terms will be developed for the consequence modeling subtask.

\section{III.5.7 Develop Scenarios}

Using the Spectrum of Accidents, scenarios will be developed in which hazardous substances can credibly be released to the environment. The scenarios identify the boundaries that must be overcome or ruptured to result in a release of each of the hazardous materials. They also describe how the substances can become hazards and which accidents will cause their release.

\section{III.6 CONDUCT CONSEQUENCE MODELING FOR HAZMAT AND RADIOLOGICAL SCENARIOS}

Task Leader: G.A. Zimmerman, Safety Analysis Engineering

\section{III.6.1 Prepare Computer Models}

The basic parameters for the various hazardous materials determined in Task III.5 will be updated and input into the applicable computer models. As mentioned earlier, these models will include TRAC, REG GUIDE 1.145, ALOHA, and ARCHIE. Other specialized models, such as MACCS or ISC, may be used on an as-needed basis subject to Committee concurrence.

\section{III.6.2 Run Computer Models}

The appropriate computer models will be run for the specific hazardous material sources and accident scenarios.

\section{III.6.3 Evaluate Results}


The results of the computer models for each hazardous material source will be evaluated and the output compared with the consequence thresholds to estimate any offsite impact. For some scenarios, the concentrations of the hazardous materials will be evaluated at several specified distances offsite.

The evaluation will include a documented uncertainty analysis for quantitative fault-tree and probabilistic analyses. However, an uncertainty analysis will not be performed for qualitative (best engineering judgement) analyses.

\section{III.7 ASSURE QUALITY OF PROJECT PROCESSES AND RESULTS}

\section{Task Leader: M. G. McCoy, Emergency Preparedness Emergency Operations}

The task leader will implement a comprehensive quality assurance program. To assure quality of this project's processes, the specific activities involved will be addressed in a Quality Assurance Plan (QAP) using the Graded Approach to application of the twenty-two Quality Requirements (QR). The results of these processes will be documented in a Quality Assurance Report (QAR) for ready access and retrievability for future reference.

\section{III.7.1 Develop Quality Assurance Plan}

The QAP will be developed in accordance with Rocky Flats Plant procedure, 1C40-QAP-02.01, "Preparation, Review, and Approval of Quality Assurance Plans". This procedure applies to all EG\&G RFP organizations and sponsors of organizations, programs, projects, facilities, and their constituent technical and administrative activities. The QAP will document the controls to be implemented to assure that an operation or activity is accomplished in a consistent manner and in accordance with requirements. 


\section{III.7.2 Maintain QAP and Develop Records}

The QAP will be maintained as a living document and be responsive to the need for changes in the project. It will be used to ensure that operations or activities implement controls that minimize a perceived risk. The records that are developed during this project will be coordinated to provide the reference base needed to document having achieved the stated objectives.

\section{III.7.3 Develop Quality Assurance Report}

The QAR will be a record of the information necersary to validate the results of the project. They will be indexed and filed in accordance with the Quality Assurance Plan to document completion of the stated objectives.

\section{8 DOCUMENT PROJECT PROCESSES, PROGRESS, AND RESULTS}

Task Leader: A. J. Petrocchi, Emergency Preparedness Offsite Programs

The task leader or designee will produce and distribute the minutes for each meeting that will become part of the archived records.

\section{III.9 REVIEW AND APPROVE FINAL REPORT(S)}

\section{Task Leader: G.A. Zimmerman, Safety Analysis Engineering}

The following is a generic description of the review and approval process. It will be repeated several times for several products to give the Oversight Committee ample opportunity for review and comment throughout the duration of the EPZ project. When documents are ready for Oversight Committee review, a classification review will be performed prior to distribution. 
III.9.1 Emergency Preparedness Review and Approval

The task leader will submit the draft final report to Emergency Preparedness who will perform a technical review of the report. Comments will be returned to the task leader for consideration and incorporation. This process will be repeated until approval for the next subtask is received.

\section{III.9.2 EG\&G Management Review and Approva.}

The task leader will submit the revised draft final report to EG\&G management who will perform a review of the report. Comments will be returned to the task leader for consideration and incorporation. This process will be repeated until approval for the next subtask is received.

\section{III.9.3 DOE/RFO Review and Approval}

The task leader will submit the revised draft final report to DOE/RFO who will perform a comprehensive review of the report. Comments will be returned to the task leader for disposition. This process will be repeated until approval for the next subtask is received.

\section{III.9.4 EPZ Oversight Committee Review and Concurrence}

The task leader will submit the revised draft final report to the EPZ Oversight Committee who will perform a technical review of the report. Comments will be returned to the task leader for consideration and incorporation. This process will be repeated until a concurrence is reached.

\section{III.9.5 Publish and Distribute Final Report}

The task leader will submit a photo-ready copy of the final report to Emergency Preparedness who will reproduce and transmit the report to DOE/RFO who in tum will transmit it to the State. 


\section{DELIVERABLES}

The following are the latest expected deliverable dates for major draft products from the tasks and subtasks mentioned above that are anticipated to be submitted to the EPZ Oversight Committee for review and concurrence. Final concurrence approval dates are highly variable and dependent on the extent of Committee comment and resulting required revision effort. Because of this variability, final concurrence approval dates are not included here except for those having received, or anticipated to receive, concurrence approval as of the date of this Project Plan. Nevertheless, final concurrence approvals are expected to be within the final date of May 1, 1996, for Task 9.0, "Review and Approve Final Report(s)." In addition, not all tasks and subtasks will generate reviewable products.

Task III.1.2 Develop Project Plan and Schedule

Deliverable: EPZ Phase III Project Plan and Schedule June 1993: Draft

March 1994: Approved (anticipated)

Task III.2 Identify Hazards Assessment Methodology

Deliverable: Guidance and Methodology

July 1993: Draft

December 1993: Approved

Task III.3 Define Spectrum of Accidents

Deliverable: Proposed Spectrum of Accidents

July 1993: Draft

December 1993: Approved 
Task III. 4 Update Radiological Release Fractions

Deliverable: Contractor Release Fraction Report

June 1993: Draft

March 1994: Approved (anticipated)

Deliverable: Updated Rocky Flats Plutonium Release Fractions

March 1994: Draft

Task III.5.1 Describe Site and Operations

Deliverable: Site and Operations Description

September 1994: Draft

Task III.5.2 Screen Hazardous Substances

Deliverable: Hazardous Materials Identification

October 1994: Draft

Task III.5.3 Develop Basis for Interim Operation (BIO) Documentation and Facility Hazards Analyses

Deliverable: None. This is a Site SAR task and is included here for information purposes only. Selected products from this task will be integrated into the EPZ Sitewide Hazards Assessment.

Task III.5.4 Develop EPZ Sitewide Hazards Assessment

Deliverable: EPZ Sitewide Hazards Assessment

November 1994: Draft

EPZ Phase III Project Plan

March 14, 1994 
Task III.5.5 Develop Site Safety Analysis Report

Deliverable: None. This is a Site SAR task and is included here for information purposes only. Selected products from this task will be integrated into the EPZ Sitewide Hazards Assessment.

Task III.5.6 Characterize Hazardous Substances

Deliverable: Source Term Identification

December 1994: Draft

Task III.5.7 Develop Scenarios

Deliverable: Scenario Identification

February 1995: Draft

Task III.6.3 Evaluate Results (Consequence Modeling)

Deliverable: Consequence Modeling Results

December 1995: Draft

Task III.7.1 Develop Quality Assurance Plan

Deliverable: Quality Assurance Plan

May 1994: Draft

Task III.7.2 Maintain QAP and Develop Records

Deliverable: Corrective Action Reports

Generated as needed. 
Task III.7.3 Develop Quality Assurance Report

Deliverable: Quality Assurance Report

March 1996: Draft

Task III.9 Review and Approve Final Report(s)

Deliverable: Final Report(s)

December 1995: Draft 


\section{REFERENCES}

1. Hodgin, C. R. et al. "Analysis of Offsite Emergency Planning Zones for the Rocky

Flats Plant - Overview." EG\&G Rocky Flats, Inc. RFP-ADD-0001 (May 1990).

2. Petrocchi, A. J. and Smith, M. L. "Analysis of Offsite Emergency Planning Zones for the Rocky Flats Plant, Phase III, Sitewide Spectrum-of-Accidents and Bounding EPZ Analysis, Charter." EG\&G Rocky Flats, Inc. RFP Pending (October 25, 1993).

3. Stalker, A. C. "Analysis of Offsite Emergency Planning Zones for the Rocky Flats Plant, Maximum Credible Accident Fourth (1988-1991) Review." EG\&G Rocky Flats, Inc. RFP-4578 (May 1992).

4. Hodgin, C. R. et al. "Analysis of Offsite Emergency Planning Zones for the Rocky Flats Plant, Evaluation of Radiological Materials." 2 vols. EG\&G Rocky Flats, Inc. RFP. ADD-0018 (January 1992).

5. Petrocchi, A. J. et al. "Analysis of Offsite Emergency Planning Zones for the Rocky Flats Plant, Development of a Screening-Level Emergency Planning Zone for Nonradioactive Hazardous Materials." EG\&G Rocky Flats, Inc. RFP-ADD-0010 (July 1991).

6. U. S. Department of Energy. "Emergency Management Guide, Hazards Assessment." (June 26, 1992).

7. EG\&G Rocky Flats, Inc. "Unreviewed Safety Question Determination Process Overview." Course Handout. Training Course 011-102-01 (June 1993).

8. U. S. Department of Energy Order 5480.21. "Unreviewed Safety Questions." (December 24, 1991).

9. Beaulieu, R. A. "The Unreviewed Safety Question Determination Process Used at Rocky Flats Plant." EG\&G Rocky Flats, Inc. A presentation given to the Emergency 
Planning Zone Oversight Committee. (February 17, 1994).

10. U. S. Department of Energy Order 5480.23. "Nuclear Safety Analysis Reports" (April 10, 1992). 
APPENDIX A: MILESTONES BASED ON EPZ AND SITE SAR INTEGRATED PROCESS

Task/Time

1993

1994

1995. 1996

Month

JJASOND|JFMAMJJASOND|JFMAMJJASOND|JFMAMJJASON

1.0 Administer Project1

2.0 Methodology1

3.0 Spectrum of Accidents1

4.0 Release Fractions 1

$1000000000000000000000000000000000000 x$

$x \times X X X 0 \times$

$x \times x \times x \times x$

$x \times x x$

5.0 Sources \& Scenarios

5.1 Describe Site1

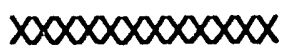

5.2 Screen Materials 1

$\times 0000000 x$

5.3 Develop BIO Documents

and Facility Hazards

Analyses2,3

$x 000000000000000$

5.4 Complete EPZ Site HA1,4

$x 0000000000000000$

5.5 Complete Site SAR ${ }^{3}$

5.6 Characterize Hazards 1

5.7 Develop Scenarios ${ }^{1}$

6.0 Consequence Modeling

6.1 Prepare Computer Codes

6.2 Run Computer Codes

$x 0000000000000000000000000 x$

$x \times x \times x \times x x$

$x \times x \times x x$

$x x x x x x$

$1000000 x$

6.3 Evaluate Results 1

$X X X X$

7.0 Assure Quality

7.1 Develop QAP1

7.2 Maintain QAP \&

Develop Records 1

7.3 Develop QAR1

8.0 Documentation

9.0 Review and Approval1

$x x x$

$x 000000000000000000 x$

$x X X X$

$1000000000000000000000000000000000 x$

$000000000000000000000000000000000 \times$

1 Draft products will be available for EPZ Oversight Committee review during this process.

2 These are individual Hazards Analyses for approximately 40 facilities developed from the site SAR process.

3 Not an EPZ Project task; included here for information only.

4 This is the Sitewide EPZ Hazards Assessment based upon the Site SAR Hazards Analyses. 


\section{APPENDIX B}

\section{EMERGENCY PLANNING ZONE OVERSIGHT COMMITTEE CONCURRENCE SIGNATURES}


As a Memher of the Oversight Committee reviewing the document titled:

\section{ANALYSIS OF OFFSITE EMERGENCY PLANNING ZONES (EPZs) FOR THE ROCKY FLATS PLANT, PHASE III, SITEWIDE SPECTRUM OF ACCIDENTS AND BOUNDING EPZ ANALYSIS, PROJECT PLAN, MARCH 14, 1994}

Colorado Department of Health

Emergency Management Unit Primary Alternate

Steve Gunderson

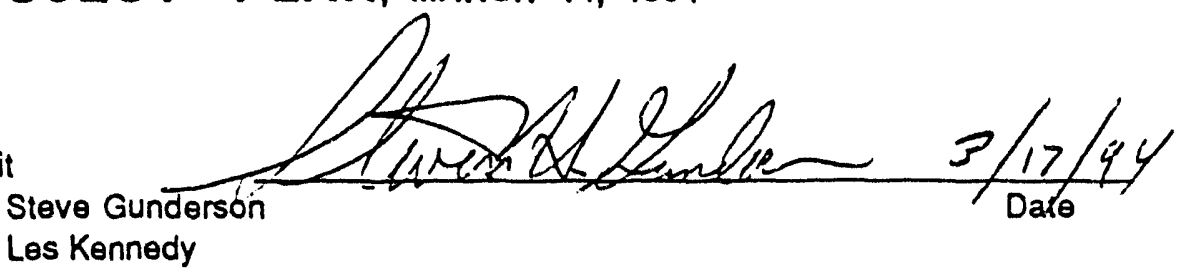

Radiation Control Division

Primary

Alternates

Bob Quillin

Date

Air Pollution Control Division

Primary

Alternate

Tony Harrison

Edd Kray

U.S. Department of Energy

Rocky Flats Office

Primary

Alternates

Richard Fox

Arch Crouse

Date

$\therefore$

Jefferson County

Emergency Preparedness

Primary

Alternate

Boulder County

Emergency Management

Primary

Alternate

Shirley Olinger

Date

Bob Ostmeyer

Bert Crist

Richard Cook
Mark Gutke

Date

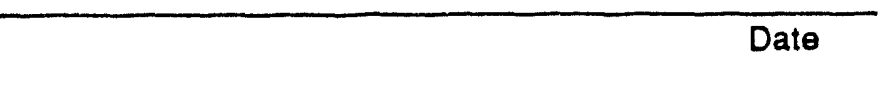

Larry Stern

Date

U.S. Environmental Protection Agency

Region VIII

Primary

Alternate

Phil Nyberg

Date

EG\&G Rocky Flats, Inc.

Emergency Preparedness

Primary

Alternates

Milton Lammering

Bob Kopplin

Date

Please Mark \& Initial:

Mark Chagnon

Rocky Petrocchi

T concur that the recommendations are technically acceptable.

I have been provided the recommendations for evaluation, but have not reviewed.

I do not concur with these recommendations.

I have been provided the recommendations for evaluation, have reviewed them, and have no comment or position.

I accept the recommendations but wish to expand on or differ with the following points:

(Attach Review Comment Sheet or other appropriate comment.) 
As a Member of the Oversight Committee reviewing the document titled:
ANALYSIS OF OFFSITE EMERGENCY PLANNING ZONES (EPZs) FOR THE ROCKY
FLATS PLANT, PHASE III, SITEWIDE SPECTRUM OF ACCIDENTS AND BOUNDING EPZ ANALYSIS, PROJECT PLAN, MARCH 14, 1994

Colorado Department of Health

Emergency Management Unit
Primary
Alternate
Steve Gunderson
Les Kennedy
Radiation Control Division
Primary
Alternates
Bob Quillin
Tony Harrison
Edd Kray

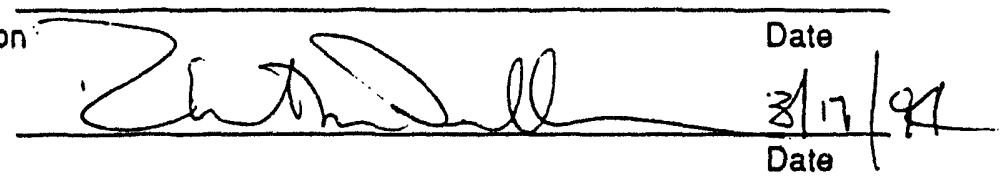

Air Pollution Control Division
Primary
Richard Fox
Alternate
Arch Crouse

Date

U.S. Department of Energy

Rocky Flats Office

Primary

. Aliernates

Shirley Olinger

Dato

Bob Ostmeyer

Bert Crist

Jefferson County

Emergency Preparedness Primary

Alternate

Richard Cook

Date

Boulder County

Emergency Management
Primary
Alternate
Larry Stern
Carol Arkland

Mark Gutke

Date

U.S. Environmental Protection Agency

Region VIII
Primary
Alternate
Phil Nyberg
Milton Lammering

Date

EG\&G Rocky Flats, Inc.

Emergency Preparedness

Primary

Alternates

Bob Kopplin

Mark Chagnon

Rocky Petrocchi

Please Mark \& Initial:

I concur that the recommendations are technically acceptable.

I have been provided the recommendations for evaluation, but have not reviewed.

I do not concur with these recommendations.

I have been provided the recommendations for evaluation, have reviewed them, and have no comment or position.

I accept the recommendations but wish to expand on or differ with the following points: (Attach Review Comment Sheet or other appropriate comment.)

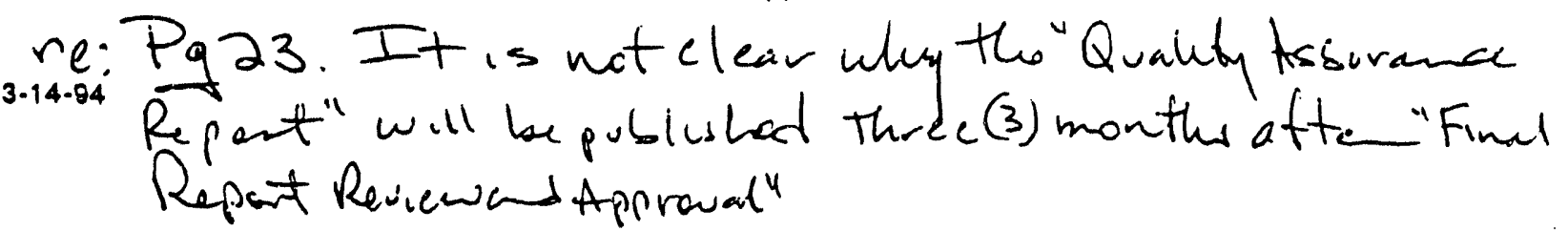


ROCKY FLATS PLANT: EMERGENCY PLANNING ZONES - PHASE III Page 1 of 1 OVERSIGHT COMMITTEE REVIEW/CONCURRENCE

As a Member of the Oversight Committee reviewing the document titled:

ANALYSIS OF OFFSITE EMERGENCY PLANNING ZONES (EPZs) FOR THE ROCKY FLATS PLANT, PHASE III, SITEWIDE SPECTRUM OF ACCIDENTS AND BOUNDING EPZ ANALYSIS, PROJECT PLAN, MARCH 14, 1994

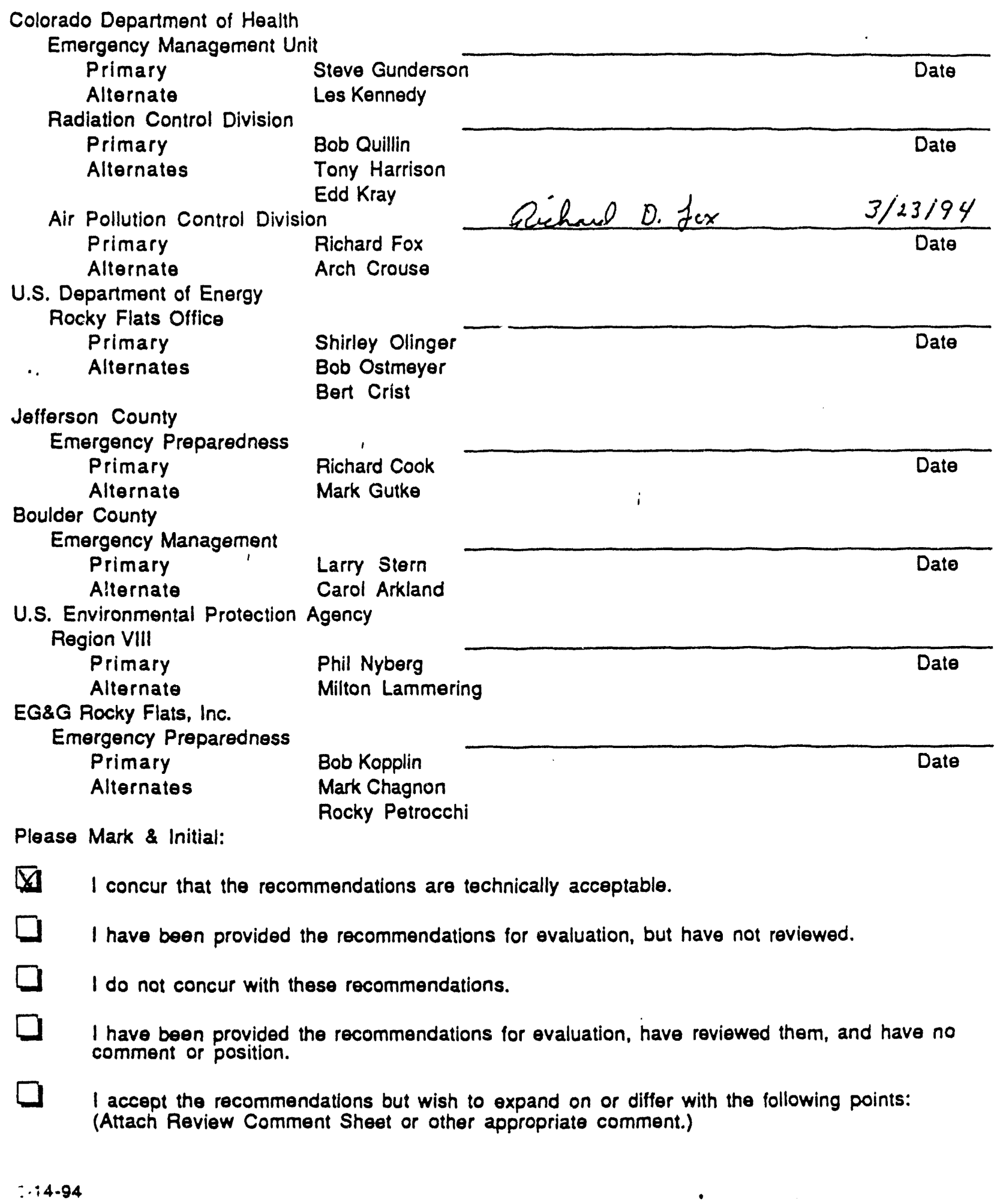


As a Member of the Oversight Committee reviewing the document titled:
ANALYSIS OF OFFSITE EMERGENCY PLANNING ZONES (EPZs) FOR THE ROCKY FLATS PLANT, PHASE III, SITEWIDE SPECTRUM OF ACCIDENTS AND BOUNDING epZ analysis, PROJECT PLAN, MARCH 14, 1994
Colorado Department of Health
Emergency Management Unit
Primary
Alternate
Radiation Control Division
Primary
Alternates
Air Pollution Control Division
U.S. Department of Energy
Rocky Flats Office
Primary
. Alternates
Jefferson County
Emergency Preparedness
Primary
Alternate
Boulder County
Emergency Management
Primary
Alternato
Steve Gunderson
Les Kennedy

Bob Quillin

Tony Harrison

Edd Kray
Primary
Alternate
Richard Fox
Arch Crouse

Shirley Olinger

Bob Ostmeyer

Bert Crist

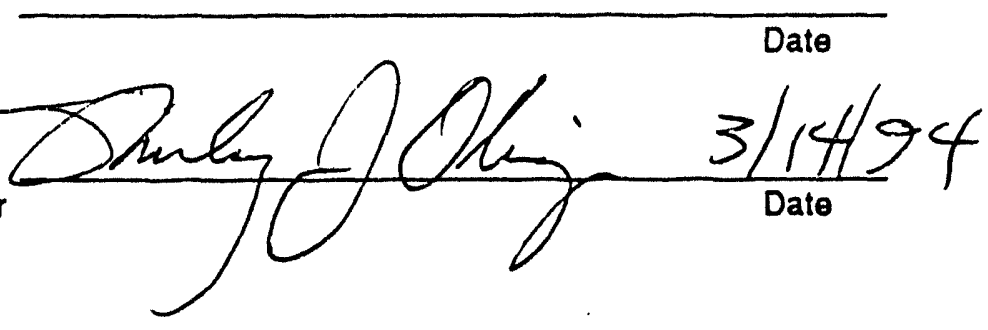

Richard Cook

Date

Mark Gutke

Date

U.S. Environmental Protection Agency

Region VIII

$$
\text { Primary }
$$

Phil Nyberg

Milton Lammering

Date

EG\&G Rocky Flats, Inc.

Emergency Preparedness

Primary

Alternates

\section{Bob Kopplin}

Date

Please Mark \& Initial:

Mark Chagnon

Rocky Petrocchi

Date

Larry Stern
Carol Arkland

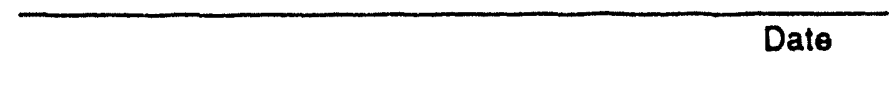


As a Member of the Oversight Committee reviewing the document titled:

ANALYSIS OF OFFSITE EMERGENCY PLANNING ZONES (EPZs) FOR THE ROCKY FLATS PLANT, PHASE III, SITEWIDE SPECTRUM OF ACCIDENTS AND BOUNDING epz analysis, PROJECT PLAN, MARCH 14, 1994

Colorado Department of Health

Emergency Management Unit

Primary

Alternate

Radiation Control Division

$$
\text { Primary }
$$

Alternates

\section{Sleve Gunderson Les Kennedy}

Bob Quillin

Tony Harrison

Edd Kray

Air Pollution Control Division
Primary
Richard Fox
Alternate
Arch Crouse

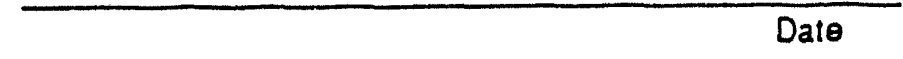

U.S. Department of Energy

Rocky Flats Office

$$
\text { Primary }
$$

Alternates

Jefferson County

Emergency Preparedness

Primary

Alternate

Boulder County

Emergency Management

Primary

Alternate

Shirley Olinger

Date

Bob Ostmeyer

Bert Crist

Richard Cook

Mark Guike

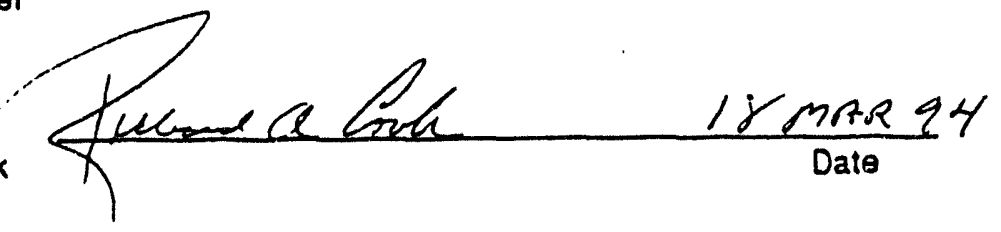

Larry Stern

Date

U.S. Environmental Protection Agency

Region VIII

$$
\text { Primary }
$$

Alternate

Phil Nyberg

Date

EG\&G Rocky Flats, Inc.

Emergency Preparedness

Primary

Milion Lammering

Alternates

Bob Kopplin

Mark Chagnon

Date

Please Mark \& Initial:

Rocky Potrocchi

I concur that the recommendations are technically acceptable.

I have been provided the recommendations for evaluation, but have not reviewed.

I do not concur with these recommendations.

I I have been provided the recommendations for evaluation, have reviewed them, and have no comment or position.

I accept the recommendations but wish to expand on or differ with the following points:

(Attach Review Comment Sheet or other appropriate comment.) 
As a Member of the Oversight Committee reviewing the document tifled:

ANALYSIS OF OFFSITE EMERGENCY PLANNING ZONES (EPZs) FOR THE ROCKY FLATS PLANT, PHASE III, SITEWIDE SPECTRUM OF ACCIDENTS AND BOUNDING EPZ ANALYSIS, PROJECT PLAN, MARCH 14, 1994

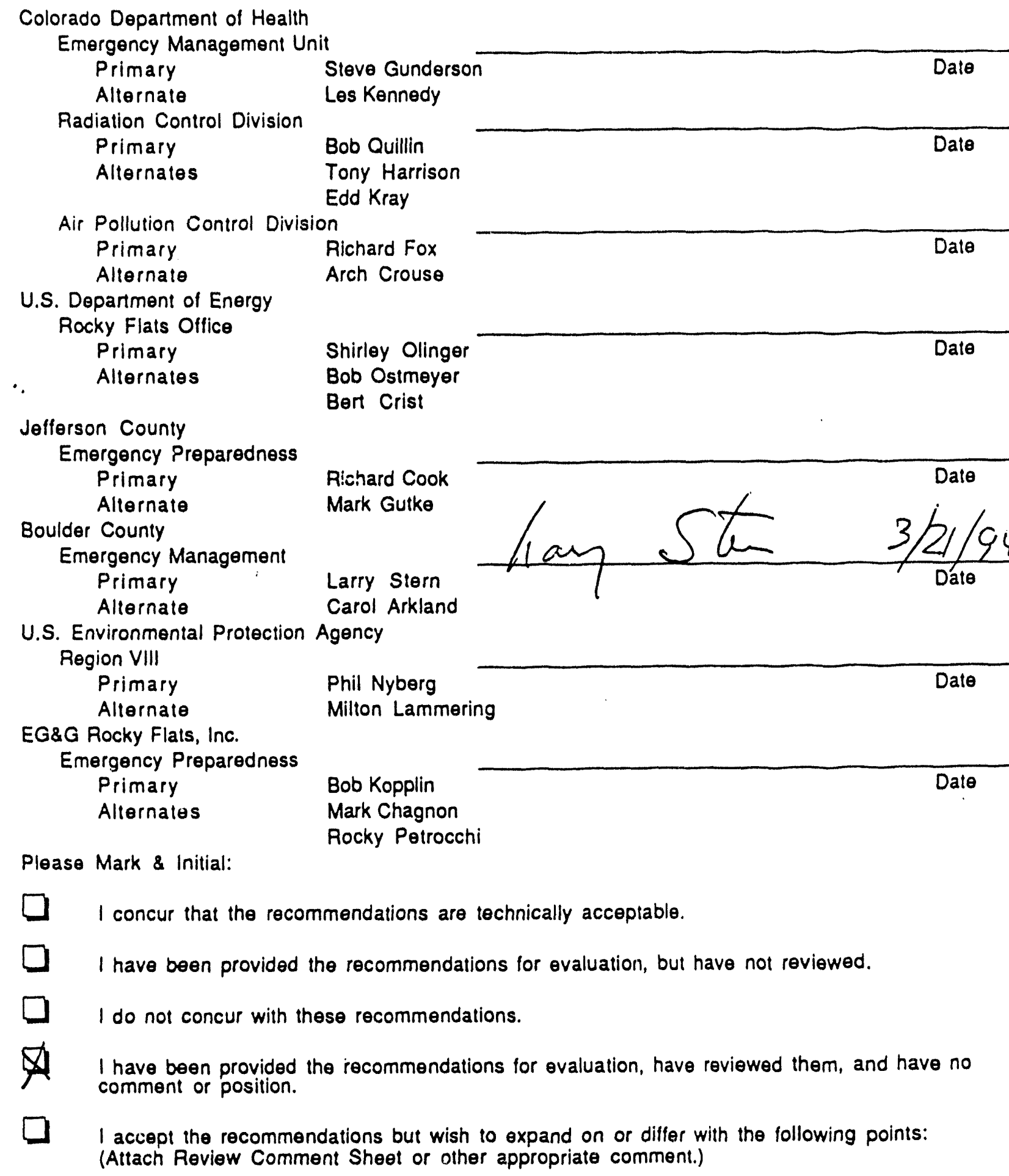

U.S. Environmental Protection Agency

Region VIII

Primary

Alternate

Phil Nyberg

Date

EG\&G Rocky Flats, Inc.

Emergency Preparedness

Primary

Alternates

Milton Lammering

Please Mark \& Initial:

Bob Kopplin

Mark Chagnon

Rocky Potrocchi

Date

I concur that the recommendations are technically acceptable.

I have been provided the recommendations for evaluation, but have not reviewed.

I do not concur with these recommendations.

A I have been provided the recommendations for evaluation, have reviewed them, and have no comment or position.

I accept the recommendations but wish to expand on or differ with the following points:

(Attach Review Comment Sheet or other appropriate comment.) 
As a Member of the Oversight Committee reviewing the document titled:

ANALYSIS OF OFFSITE EMERGENCY PLANNING ZONES (EPZs) FOR THE ROCKY FLATS PLANT, PHASE III, SITEWIDE SPECTRUM OF ACCIDENTS AND BOUNDING epz analysis, PROJECT PLAN, MARCH 14, 1994

Colorado Department of Health

Emergency Management Unit

Primary

Alternate

Radiation Control Division

Primary

Alternates
Steve Gunderson

Les Kennedy

Bob Quillin

Tony Harrison

Edd Kray

Air Pollution Control Division

$\begin{array}{ll}\text { Primary } & \text { Richard Fox } \\ \text { Alternate } & \text { Arch Crouse }\end{array}$

Date

U.S. Department of Energy

Rocky Flats Office

$$
\text { Primary }
$$

. Alternates

Jefferson County

Emergency Preparedness

Primary

Alternate

Boulder County

Emergency Management

Primary

Alternate

Arch Crouse

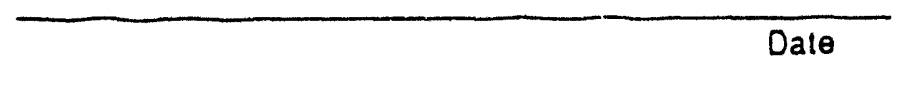

Dalo

Shirley Olinger

Date

Bob Ostmeyer

Bert Crist

Date

(1)

Richard Cook

Date

Mark Gutke

Larry Stern

Carol Arkland

U.S. Environmental Protection Agency

Region VIII

Primary

Alternate

Phil Nyberg

Milton Lammering

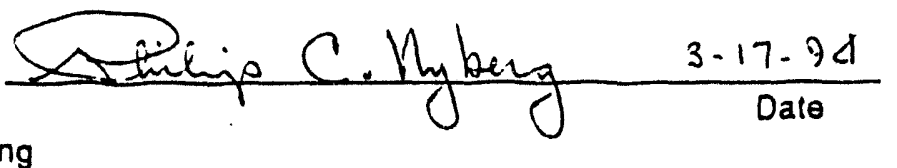

EG\&G Rocky Flats, Inc.

Emergency Preparedness

Primary

Alternates

Bob Kopplin

Date

Please Mark \& Initial:

Mark Chagnon

Rocky Petrocchi

X I concur that the recommendations are technically acceptable.

I have been provided the recommendations for evaluation, but have not reviewed.

I do not concur with these recommendations.

I have been provided the recommendations for evaluation, have reviewed them, and have no comment or position.

I accept the recommendations but wish to expand on or differ with the following points:

(Attach Review Comment Sheet or other appropriate comment.) 
As a Member of the Oversight Committee reviewing the document titled:

ANALYSIS OF OFFSITE EMERGENCY PLANNING ZONES (EPZs) FOR THE ROCKY FLATS PLANT, PHASE III, SITEWIDE SPECTRUM OF ACCIDENTS AND BOUNDING EPZ ANALYSIS, PROJECT PLAN, MARCH 14, 1994

Colorado Department of Health

Emergency Management Unit Primary

Alternate

Steve Gunderson

Les Kennedy

Radiation Control Division

Primary

Bob Quillin

Tony Harrison

Alternates

Edd Kray

Air Pollution Control Division

Primary

Alternate

U.S. Department of Energy

Rocky Flats Office

Primary

$\therefore \quad$ Alternates

Jefferson County

Emergency Preparedness

Primary

Alternate

Boulder County

Emergency Management

Primary

Alternate

Richard Fox

Arch Crouse

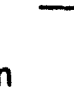

Date

Date

Date

Bert Crist

Richard Cook

Date Mark Gutke

Larry Stern

Date

U.S. Environmental Protection Agency

Region VIII

Primary

Alternate

EG\&G Rocky Flats, Inc.

Emergency Preparedness

Primary

Alternates

Phil Nyberg

Date

Milton Lammering

Please Mark \& Initial:

Bob Kopplin

Mark Chagnon

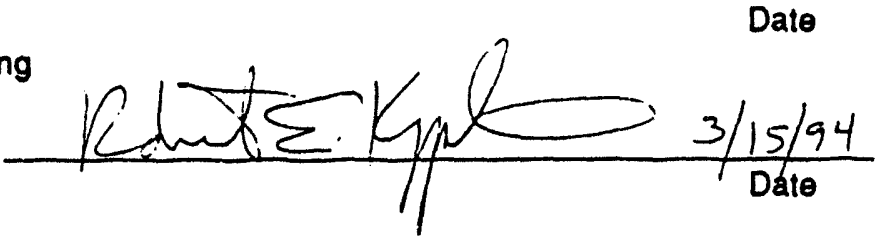

Pocky Petrocchi

I concur that the recommendations are technically acceptable.

I have been provided the recommendations for evaluation, but have not reviewed.

I do not concur with these recommendations.

I have been provided the recommendations for evaluation, have reviewed them, and have no comment or position.

I accept the recommendations but wish to expand on or differ with the following points: (Attach Review Comment Sheet or other appropriate comment.) 

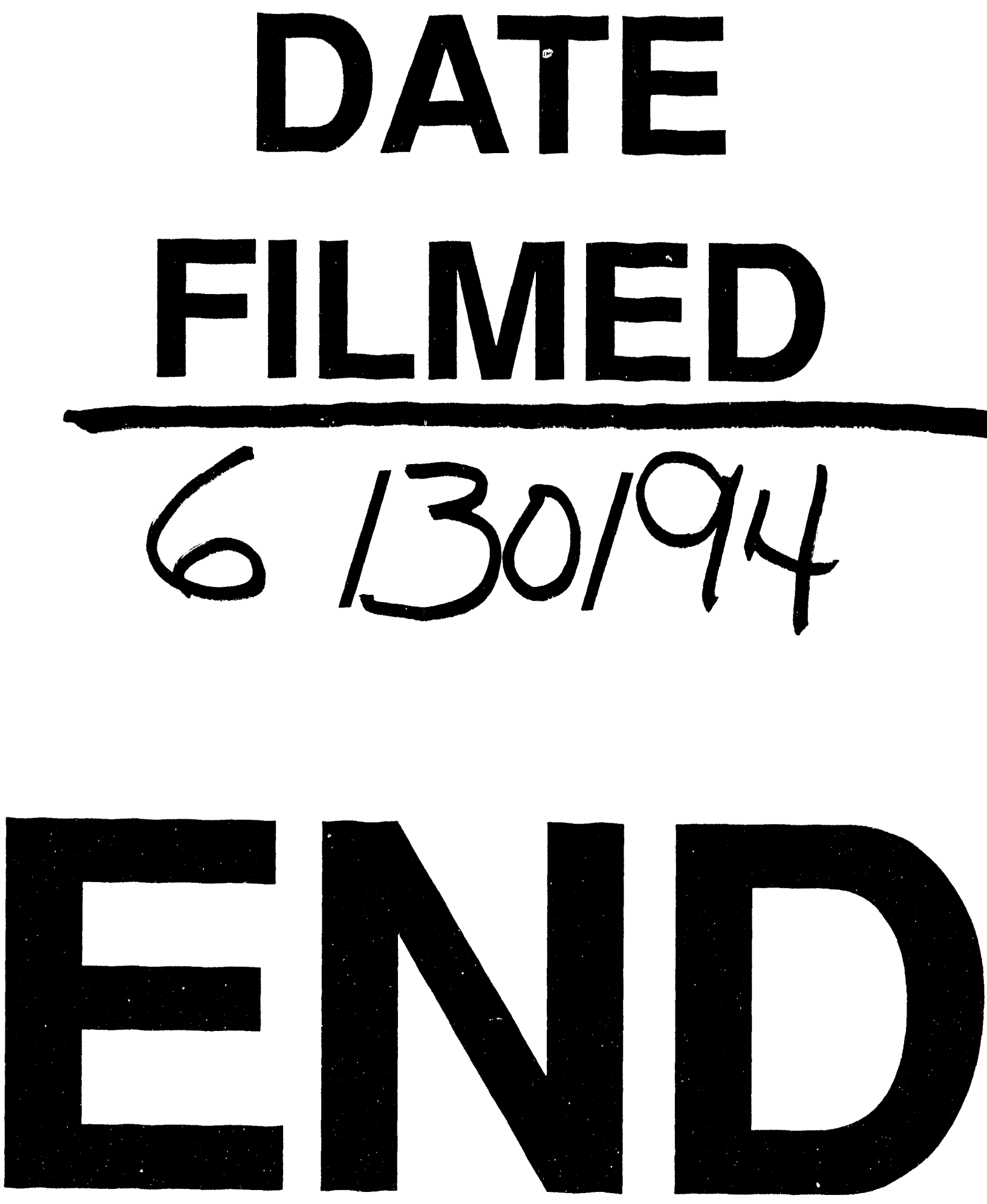